\title{
Environmental analysis of two inventories with more than 10 years of difference between natural and created wetlands
}

\begin{abstract}
The global importance of natural wetlands lies in the ecosystem services it provides to the planet; however, its destruction by anthropogenic activities of high economic performance has increased costs for conservation, restoration, inventory and monitoring, which is not always performed before handling. There are several drawbacks to monitor the loss of wetlands, including: climate variability and natural geological drift; unplanned growth of the population; including those created or artificial natural wetland, for example, dams; the difficulty to match the natural environmental value of the created; and the scarcity of historical records to track your loss. Therefore, This contribution analyzes and compares the results of two wetland inventories of Mexico, with the aim to estimate the loss or increase of natural wetlands and created (dams) based on reservoir volumes; To do this, inventories of the Comission Nacional del Agua (CNA) in 1999 and 2012 were used in the case of inventory of mangroves as individual wetlands and their change was estimated based on information from the Comission Nacional de la Biodiversidad (2013). From the above it was determined that in a period of just over 10 years volumes increased by $16 \%$ in both wetlands. Regarding mangrove, it was chosen as representative of the

state where Nayarit estimated $15 \%$ loss in a period of approximately 10 years
\end{abstract}

Volume 2 Issue 3 - 2018

\author{
Guadalupe de la Lanza Espino,' Francisco \\ Abarca, ${ }^{2}$ Salvador Hernandez Pulido' \\ 'Department of Zoology, Universidad Nacional Autonoma de \\ Mexico, Mexico \\ ${ }^{2}$ The Arizona Game and Fish Department Phoenix, USA
}

Correspondence: Guadalupe de la Lanza Espino, Department of Zoology, Bilogía Institute, National Autonomous University of Mexico, Botanical Garden Third Circuit Exterior, Ciudad Universitaria s/n, CP 04510, Mexico, Tel 015556229/32, Email gdlle@unam.mx,gdlle@ib.unam.mx

Received: June 0I, 20I8 | Published: June 08, 2018

Keywords: inventories, Mexican wetlands

\section{Introduction}

Natural wetlands are dynamic systems can disappear or be created as a result: the differential sediment of adjacent areas with loss or gain of surface and / or volume as climate, subsidence (sinking bottom), Evolution of river basins, erosion, and in the case of coastal by rising sea level, ${ }^{1}$ among others. However, the inclusion of built: created dams, ponds raising fish and shrimp farms, irrigated farmland, rice paddies, dams, hydroelectric dams, pools oxidation among others, ${ }^{2}$ has erroneously increased wetland ecological conception unequally. This inclusion represents certain threats to the ecosystem of natural wetlands ecosystem including adjoining both flora and fauna that depend on wetlands for their vital functions. Originally the Ramsar Convention was aimed at protecting environments used by migratory waterbirds. For its part, the National Commission on Protected Areas (National Commission of Natural Protected Areas CONANP, National Water Commission CONAGUA, Statistics on Water in Mexico Edition 2016 Government of the Republic, SEMARNAT) refers within the Ley de Aguas Nacionales ${ }^{3}$ a definition of wetlands as transition zones between aquatic systems and terrestrial areas that are temporary or permanent inundation, whether or not subject to tidal influence, such as swamps, bogs and marshes, whose limits are constituted by the type of hydrophilic vegetation permanent or seasonal presence, areas where the soil is predominantly water and lacustrine or permanently wet soil areas by natural groundwater discharge. Moreover, the Ramsar Convention is currently proposing a broader definition as well as consider swamps, marshes, lakes, rivers, peatlands, oases, estuaries and deltas, also considered artificial sites such as reservoirs (dams), salt and marine areas next the coast whose depth at low tide does not exceed six meters, which can include mangroves and coral reefs. This concept is more focused on natural wetlands (http://www.geoenciclopedia.com/humedales/). The Ramsar Convention is currently proposing a broader definition as well as consider swamps, marshes, lakes, rivers, peatlands, oases, estuaries and deltas, also considered artificial sites such as reservoirs (dams), salt and marine areas near the coast whose deep at low tide does not exceed six meters, which can include mangroves and coral reefs. This concept is more focused on natural wetlands (http://www. geoenciclopedia.com/humedales/).

Warner ${ }^{4}$ defined the wetland environment as that saturation or sustained recurrent flood or near the surface, hydric soils, physical, chemical and biological and hydrophilic vegetation individual characteristics. These features always be present except where certain physiochemical, biotic or anthropogenic factors have eliminated or avoided development. A natural wetland three elements must exist: the substrate (sediment), water and vegetation condition have some anthropogenic or created. However, within the definition of Ramsar include artificial breeding ponds to fish and shrimp, salt marshes, reservoirs, pools of sewage and wetlands channels. According conception of Colombia ${ }^{6,7}$ "inland wetlands (and even coastal) are of great importance not only from the ecological point of view but also socioeconomic, of its multiple functions, values and attributes, which are essential for society as a whole. However, altering its natural balance by human activities has an economic, social and ecological cost. An "ecosystem approach" is important for the management of land, water and living resources, either to maintain or restore natural systems, their functions and values, so that conservation and sustainable use of a form is promoted fair and equitable, through the integration of environmental factors, Cabrera Sánchez et al., ${ }^{8}$ 
developed a proposal that includes some environmental parameters where the authors obtained from different institutions, and since they did not have continuous, were based in different years depending on the availability of information. They considered geomorphological, geological features, both aquatic, riparian vegetation and even forestsoil-water and called created comprising: dams, aquaculture ponds, farming, ponds and sedimentation control, among others. Rector Strategy Paper" defines wetlands as "area of transition between aquatic and terrestrial systems, which are permanent or temporary flooding, both inland and coastal, whether or not subject to tidal influence. Indicate that these ecosystems have annual and interannual fluctuations lead to significant changes in their properties and functions, so it is difficult to define the moment when the properties that define systems, clearly at the ends of environmental gradient, give way to a wetland or vice versa. Furthermore, the hydric conditions are defined in turn by the interrelation of topographic, geological and climatic factors and the basin where the wetland is located, and uses, In natural wetlands must take into account not retain their original dimensions landform and geological dynamics and climatic evolution as imperishable; therefore inventories are partial, which makes necessary to have a database sufficient in both its size and the characteristics of the adjacent area, so it is advisable to periodically evaluate, depending on the particular dynamics which are defined; reason to exclude all anthropogenic subject not only the climate but the increase in population and economic development.

Mangroves have been considered as natural wetlands and forests are species of woody plants growing in ponds, riverbanks and coastlines protected tropical wave. Due to its coastal location they are always in contact with water bodies of marine origin, or in combination with the water coming through runoffs even at river mouths. (http://ecologosdelplaneta.blogspot.mx/2012/04/manglareshumedales.html). According to $\mathrm{CONABIO}^{10}$ this ecosystem is important because it provides benefits or recognized as flood control, hurricane protection, nutrient source and capture greenhouse gases widely effect environmental services, among others; According to $\mathrm{FAO}^{11}$ water recharge groundwater, among other services. In Mexico, Olmsted $^{12}$ estimated more than 3.3 million hectares of wetlands, accounting for $0.6 \%$ of the world's wetlands, for their Dugan $\mathrm{p}^{13}$ recognized less than two million, of which $1,250,000$ hectare (ha) have correspond to wetlands 650000 ha coastal and inland wetlands have to. More recently, the figures provided by the National Forest Information System of Mexico indicate that in 2002 there were approximately 4.5 million ha of hydrophilic vegetation, within which mangroves, popales, tulares, hillocks and gallery vegetation were pooled, among others. According to $\mathrm{CONABIO}^{14}$ in 2015, $7,75,555.5$ ha has existed nationwide with a profit compared to 2010 , due to increased mangrove, disturbed mangrove and other wetland. As relates to a dam, also considered wetland is a thick wall or dam built of concrete, stone or other material that is built on a river to retain rainwater or river water. It is an artificial reservoir of water to use it in irrigation, human supply or produce energy stocks (https://es.scribd. com/document/328527250/Definicion-y-Partes-de-La-Represa).

Altering water regimes damming especially large for various human activities accelerated growth, not always properly planned due to various factors. Based on Jiménez ${ }^{15}$ (https://prezi.com/ jiemlwncppaf/vida-util-de-las-presas/ ) the dams may be divided according to their use: storage, and regulatory diverter which can bring environmental benefits and economic as flood control, power generation and water availability for human consumption and irrigation; however present certain problems to damming a river because the natural hydrological regime is altered, there limnological changes, modifications in low areas that disrupt biological cycles, displacement of biotic communities, changes in adjacent terrestrial áreas among others; for this sense is uncertainly the inclusion of this type wetlands into natural wetlands which is characteristics by ecological services. It should be noted that not all irregularities soil or land fill temporary or permanent water could be considered a wetland because it does not meet certain basic environmental services, ecologically speaking; for that, the site has to contain water for a period sufficient to flourish a population of aquatic plants with the possible inclusion of a typical fauna such as lakes beach. ${ }^{16}$ Therefore, due to the lack of uniformity in definitions and types of wetlands by natural or human-induced activities and its expansive factors should be chosen and clarify the objectives of inventories and consequently an appropriate methodology. Despite the differences identified above between natural and created wetlands, the objective of this work was a comparative estimate of the variation spatiotemporal surfaces and volumes between two inventories Mexico (including the natural wetland and created, dams in particular) with differences of more than 10 years, approximately. Furthermore, estimating changes surfaces mangrove considered natural wetland, over a period of 10 years.

\section{Materials and methods}

Given the importance of temporal variation (variability between years) and spatial wetlands in Mexico and taking into account the lack of records, for the present study only counted the inventory published by the National Water Commission ${ }^{17}$ and the National Water Commission ${ }^{18}$ published in 2014. This analysis was conducted at the system level as biological hierarchy; also based classification Cowardin et al., ${ }^{19}$ of: marine, estuarine, riberino, lacustrine and palustres systems also included the "created" used by the CONAGUA, which considers the dams as wetlands. Note the lack of databases of filling and loss records of certain dams by state and federal governments; consequently, some of the results came from what was published in the local media information. In the case of inventory of mangroves it was based on information from the $\mathrm{CNA}^{17}$ and the National Biodiversity Commission, ${ }^{10}$ for a period of 10 years.

\section{Results and discussion}

In 1999 was calculated 9615 of water bodies that had $7,772,928$ hectars of wetland ; according CONANP until February 2014 (http://ramsar.conanp.gob.mx/la_conanp_y_los_humedales. php) 142 wetlands were recorded and referred SEMARNAT an area of 9,924,624 ha (http // Ramsar.conanp.gob.ms / docs./PNH_Consulta. pdf); for its part Ramsar in 2017 reported 8,657,057hectars and Gonzalez Villareal (http://www.agua.unam.mx/ivagua/assets/pdfs/ presentaciones/guadalupe_mariles.pdf) based on satellite imagery reported 10,033,623 ha with a greater difference of 108,999 ha over the previous. In the present study, to estimate the loss of wetlands, the total area of that by $\mathrm{CNA}^{17} 7,772,928$ ha with CONAGUA 12 years later with 9,208,974 hectares were compared; i.e about three million more than accounted for $16 \%$ difference. Based on these last two references, surfaces created calculated by CONAGUA against dams plus border estimated by the CNA's, showing a difference of 24.714 ha in favor of the latter were compared. For more, lakes equivalent to the fluvial plus lacustrine a difference of greater than 1,267,897 lakes it has calculated; in the case of lagoons equivalent to estuarine to a difference of 426.131ha more calculated in the latter; finally, in the case of palustres compared to the marshes (if it were the equivalent) have a difference of $1,582,901$ ha for the palustres (Table 1) it was estimated. These differences may result from the definition itself, the methodology used; different years have made the inventoried with different climate and even the type of vegetation created. With respect to those created when the inventory is made in 1999 had 2,566 dams, about; in the year 2012 were 4,461 dams, published by CONAGUA ${ }^{20}$ 
this was $58 \%$ more, but in this analysis the increase of wetlands created not only for the reasons already mentioned, but also by not perceived population growth with a massive farming consumptive has decreased annually the volume and surface dams faster than they fill up, leaving large desiccated uncovered areas, such as the dam La

Table I Comparison of surface wetland system level between 1999 (a) and 2005 to 2012 (b)

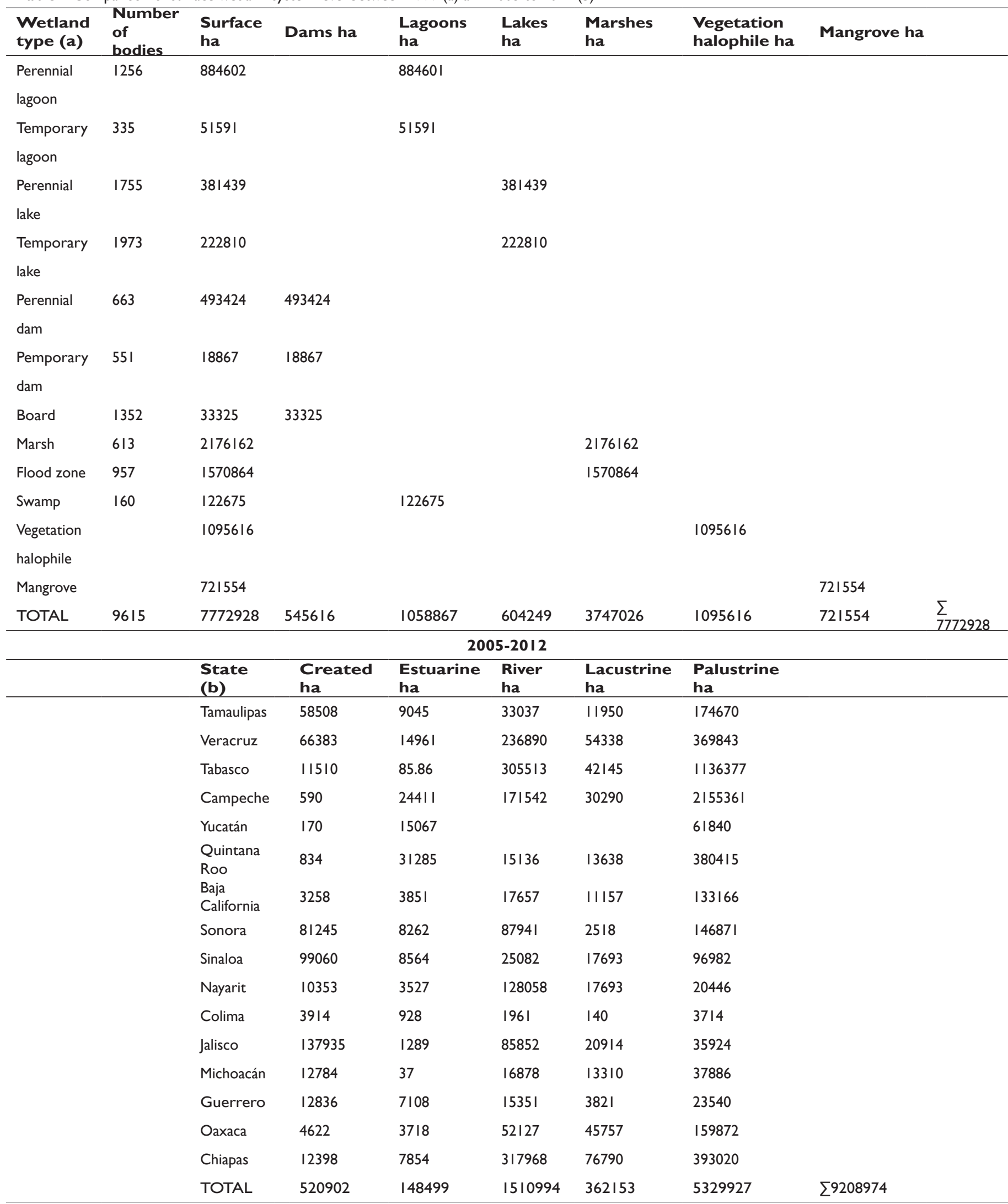

Citation: de la Lanza EG,Abarca F, Pulido SH. Environmental analysis of two inventories with more than 10 years of difference between natural and created wetlands. Int J Hydro. 2018;2(3):353-362. DOI: I0.15406/ijh.2018.02.00096
Rosilla 11 in Durango state found in the 2018 with 1\% of its capacity; another example is the water uptake Queretaro State was only 8\%; all of this associate to annual or interannual drought that is not always the same. 
In relation to the population increase, only grew $4.7 \%$ between 1999-2013 which demanded water and that for various kinds industry population have increased consumptive water requirements (e.g.

consumer agriculture irrigation water obtained from dams); i.e. there are losses in the volume of water that not always return to their sources, in other words, it is not returned to the same volume as half extracted. ${ }^{21}$ Increased agricultural activity from 1980 to 2015 was $21 \%$ in 35 years $(0.6 \%$ per year $){ }^{22}$ especially in a consumptive activity that impacts not only the dams, but also to natural wetlands various spatial and temporal magnitudes. However, the variation in the volume of natural wetlands (decrease in the dry season or increase in the rainy season) as well as management of land use, particularly deforestation of watersheds for agriculture, has led to siltation and so both increased loss flooded depth at the same rate of annual rainfall. ${ }^{23}$ Also consider that there is loss of natural wetlands, but others are created by hydrogeological dynamic, time-lapse with different scales. In the case of wetlands created, there may be an increase or decrease in surface area/volume according to the type of human activity, but also through silting by high sediment loads that reach them by runoffs, results of adjacent deforestation, If the dams are considered as wetlands, although created, it should be considered that do not have the variety and number of ecological environmental services provided by natural wetlands; it must also take into account that exhibit marked intra- and inter-annual variation in their areas and volumes for the annual weather pattern and its tendency to change sometimes leading to losses of close to $90 \%$ of the volume that were built to the Maximum Ordinary Water Level (MOWL) result of large droughts from the 70's of the last century such as Aguamilpa dam in Nayarit that has come to frequent losses of up to $56 \%$, hardly razons that they could not be considered as wetlands (Ramsar first defined as having a more ecological approach). In Mexico, This type of artificial reservoirs are filled via rain or river, losing once surface and volume continuous consumption of water to various anthropogenic activities not only for agriculture, but industry and urban supply, compared with certain natural wetlands that can maintain levels sufficient and even minimum for survival of aquatic flora and fauna and conservation, but also depend on the extraction for other human uses. It should also be noted that dams can exceed the Maximum Ordinary Water Level (MOWL) in very rainy years, but not most of the time and involvement is basically human populations.

The investigators related to water ${ }^{24}$ states that "during the 70 s and $80 \mathrm{~s}$ of last century, the main use of artificial wetlands as stations treatment of urban wastewater. But it was from the 90s of last century, when these wetlands have been used successfully in the treatment of various industrial wastewaters. Consider that within the sedimentary substrate such wetlands have the function of removing pathogens by adsorption, filtration or predation; also the removals of heavy metals such as cadmium, zinc, copper, chromium, mercury, selenium, lead ". In this regard, the present authors believe that, by virtue of their chemical reactivity, metals can remain for long periods and even be more toxic to benthic organisms, seen from the point of ecology of natural wetlands. Why this type of artificial wetlands should retain the name of stations treatment of urban waste water and/or any industrial type (such as power generation); therefore one more reason that dams should not be considered as artificial wetlands or even being created because, in addition to its extensive and frequent and heavy losses, just have some ecological services similar to natural wetlands. It should be noted that there is a trend towards increased construction of dams currently reach $>5000$ according to CONAGUA ${ }^{25}$ for the water needs of a population of accelerated growth, but apparently integrated into the environment planning, so it is unavoidable determine variability of surface and volume dammed with some regularity, through a monitoring plan that would indicate the loss of both natural wetlands and the increase created and integrate them into construction needs; CONAGUA ${ }^{25}$ has proposed a monitoring every five years. In the present study, despite the population growth and water needs handled through damming, not a marked tendency to build dams on a 13-year period was observed, as shown in Table 1, given the similarity between the dammed surfaces. This could be justified by the lack of reliable records and continuous behavior of dams by parastatals and federal offices, responsible for monitoring and thus management of water resources. Secondly, the influence of climate and its variability that does not allow a comparative analysis of the change of water covered surfaces.

In order to locate dams by state and estimate its behavior, it was considered important to include the map of Mexico with the Administrative Hydrologic Regions ${ }^{18}$ (Figure 1). To estimate the gain or loss of stored volume of a dam was since filled after its completion to where he had records (Table 2). All dams here analyzed showed variations according to their size or dammed volume and location (Figure 1), as in dams built in large basins (rivers Bravo, Grijalva-Usumacinta, Fuertes, Sinaloa, Culiacan, Lerma-Santiago, Balsas, Santo Domingo, etc.) where the maximum loss point has reached $>56 \%$ of the stored volume. Although the dams are distributed throughout the country, the largest number is located in the central and northern climates dry to very dry (Figure 1) the interval exhibit appreciable decrease regionalization; it should be noted that although region 1 has four dams, these are smaller and there was no published information. It should be noted that recent local reports refer to the start of 2018 losses $<5 \%$ of stored volume especially in arid or semi arid regions of the north and center of the country, as already he mentioned. The chosen dams located on the Pacific wáter-shed, corresponding to administrative regions II and III (Figure 1) including northeastern states like Sonora and Sinaloa (Figure 2), some are large reaching losses to $<55 \%$ of its volume dammed (Lazaro Cardenas and La Angostura) as can be seen in Table 2, resulting in significant changes of these wetlands created. This loss can be high in abnormally dry years by climatic effect or intensive use in agriculture, although in other cases of extraordinary years of precipitation, the opposite happens surpassing the MOWL. Despite the extreme climatic conditions of these regions, $\mathrm{CONABIO}^{14}$ estimates that nationally this administrative region is the second largest area of mangrove $(24.2 \%)$; state level Sinaloa has $41 \%$ and Nayarit 39\%. Within the region III also includes the state of Durango (Figure 2) the range of the stored volume loss has ranged from 5 to $23 \%$; it should also be noted that are smaller. In this administrative region as in others referred by CONAGUA $^{26}$ there are not enough records to analyze dams and wetlands created (Table 2).

Administrative Region IV (Figure 2) shares dams with five states (Michoacan, Guerrero, Morelos, Tlaxcala and even Jalisco) of different sizes and some of them located in series within a basin. The Balsas River is a waterway of the largest in Mexico consists of various rivers and their watersheds, with the highest number and size in the state of Guerrero. Loss percentage has ranged from 13 to $49 \%$. Compared to other regions mentioned above, the region IV presents greater variety of climates, Garcia ${ }^{27}$ which results in precipitation diversity and consequently the filling level of these wetlands created. In the $\mathrm{V}$ region are two pieces of different size and Mexican Revolution Benito Juarez located in Guerrero and Oaxaca respectively (Figure 2). In the case of the former it does not have records of their losses and 
in recent days has been used as a derive dam to control flooding, in addition to agricultural use. As relates to the Benito Juarez record for 24 years, it has reached a maximum loss of up to $50 \%$. Administrative region called Rio Bravo VI (Figure 2), which includes four states: Chihuahua, Coahuila, Tamaulipas and Nuevo Leon, with 16 dams of different volumes, presented in some years losses have ranged from 0 to $50 \%$. Notably, the dam San Gabriel Mexican or Federalism located in Durango, is the one that has lost the highest percentage in the stored volume, possible outcome of the local climate. In the administrative region VII are four dams, two in Durango one large volume dammed for flood control and agriculture, but with a maximum loss of $50 \%$ within 26 years of records; the two remaining located in Zacatecas (Figure 2) one of them is El Chique lower capacity, which in 2012 was $27 \%$ of its volume due to the lack of rain, ${ }^{28}$ but in 2018 was reported locally filling up more than $90 \%$, the weather determining association. VIII administrative region including four states (Figure 2 ) is containing more dams and more years of records; These include five major dams: Plutarco Elias Calles, Trigomil, El Cajon, La Yesca and Aguamilpa latter has duly registered to $<56 \%$ decrease in volume dammed.

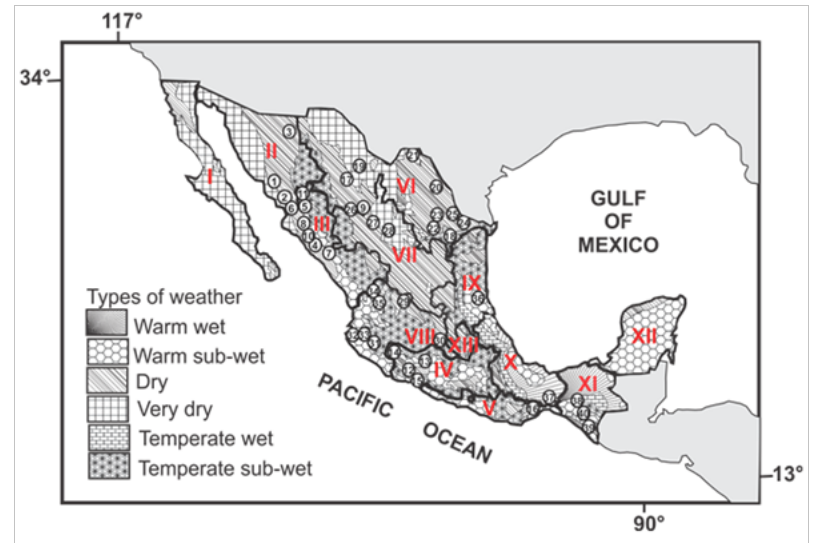

Figure I Hydrologic Administrative Regions (black line with red numbers), dams (open circles), achurated (climates) in Mexico.
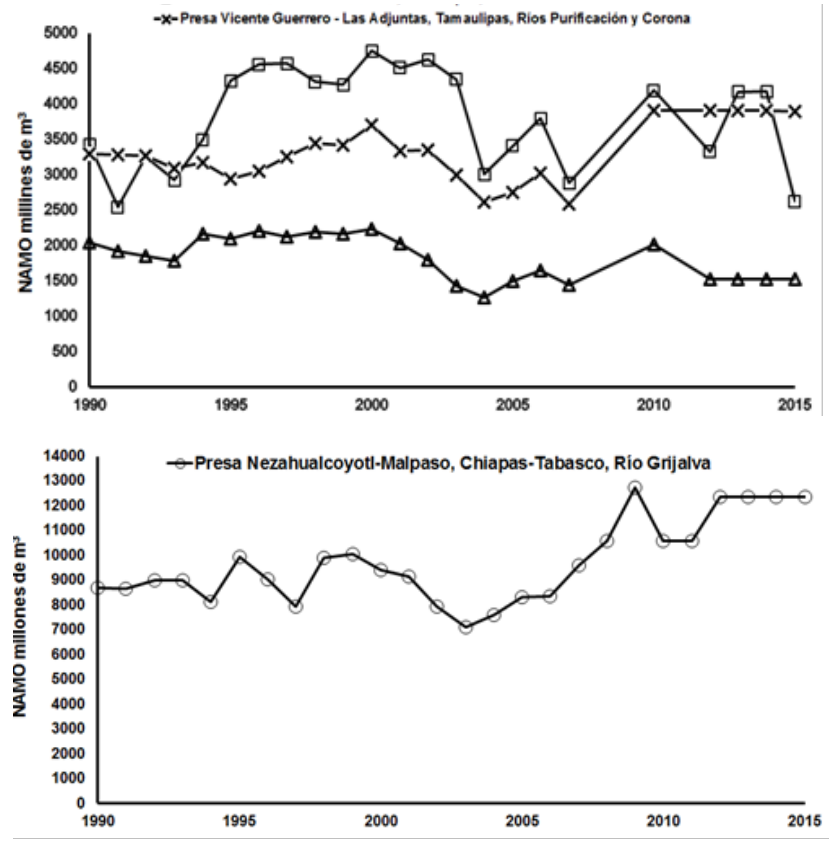

IX or administrative region is the Northern Gulf Chicayan dam (Figure 2) within 10 years of records there was a maximum decrease of the dammed point of $41 \%$ volume. In this region there are important dams; they include: Zimapán (26\%), Las Adjuntas (49\%) and El Estudiante Ramiro Caballero (48\%) among others (Table 2). In the administrative region $\mathrm{X}$ or Gulf $\mathrm{Center}^{26}$ there are two major dams, the Temazcal with $49 \%$ loss of point dammed volume, according to the records of 25 years and the Cerro de Oro with a loss of $44 \%$, with based on information contained in 22 years.

The administrative region XI or South Border (Figure 2) which it includes the states of Tabasco and Chiapas with four hydroelectric plants built on the Grijalva River basin: Malpaso, La Angostura, Chicoasén and Peñitas with information 21 to 25 years, particularly with a point La Angostura loss of $49 \%$ of its stored volume within that period and Netzahualcóyotl or Malpaso with $50 \%$ maximum point and minimum of $2 \%$. This is a region that has large natural wetlands besides the dams (Table 2). CONAGUA ${ }^{26}$ considers that national Chiapas has $6.3 \%$ of mangrove, this type of natural wetland. Also it refers to a national level, has the largest area Campeche mangrove (25.6\%) followed by Quintana Roo (16.7\%), even corresponding to the region X111. The administrative region XII is located in the Yucatan Penisula (Figure 2) where it is no major rivers and consequently of dams, but where large areas of wetlands, mainly represented by mangrove has the largest area nationwide are located ( 54.4\%) as noted CONABIO. ${ }^{14}$ XIII or administrative region Valley Mexico (Figure 2) has four dams losses its stored volume between 11 to $32 \%$; however, only information was available a year built, where there was a significant loss of volume dammed except for the Endhó dam with three years of records. Upon analysis of natural wetlands against created (dams), include the following distinguishable characteristics; e.g. Origen, temporary wide variations in reservoir volumes that do not allow the establishment of biological communities, differences in the complexity of environmental services. It is important to say that the create wetland come from the change of land use for different management, and some of them exclusively to anthropogenic activities, among other justification in the environment, therefore is not possible to consider the created as true wetlands.

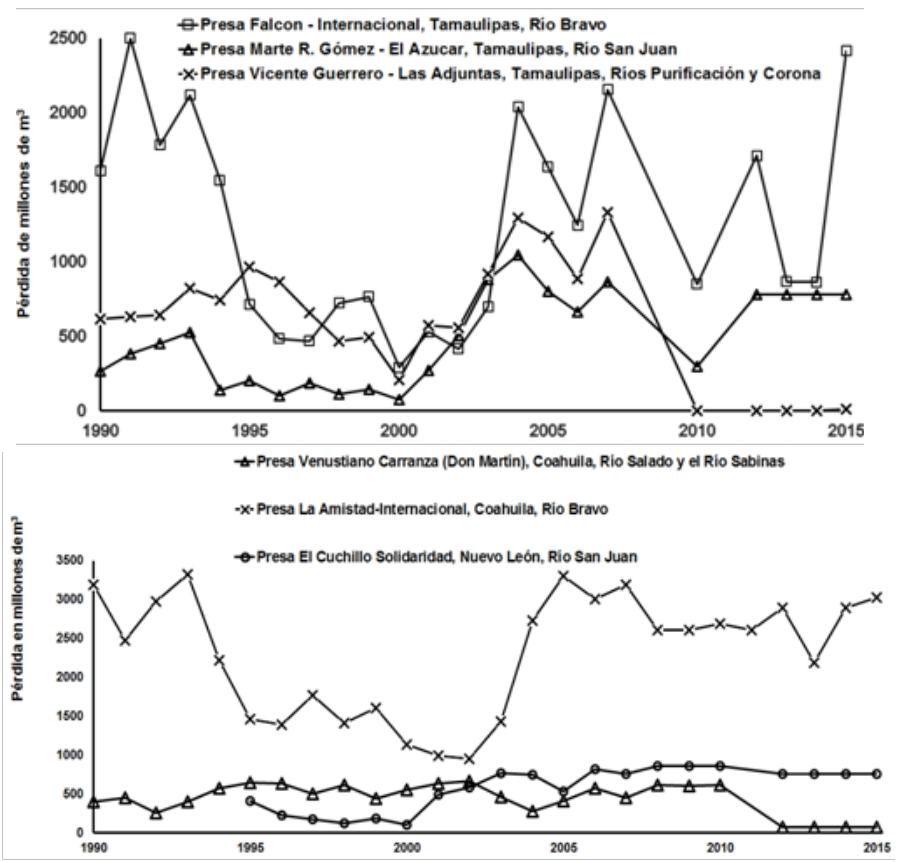



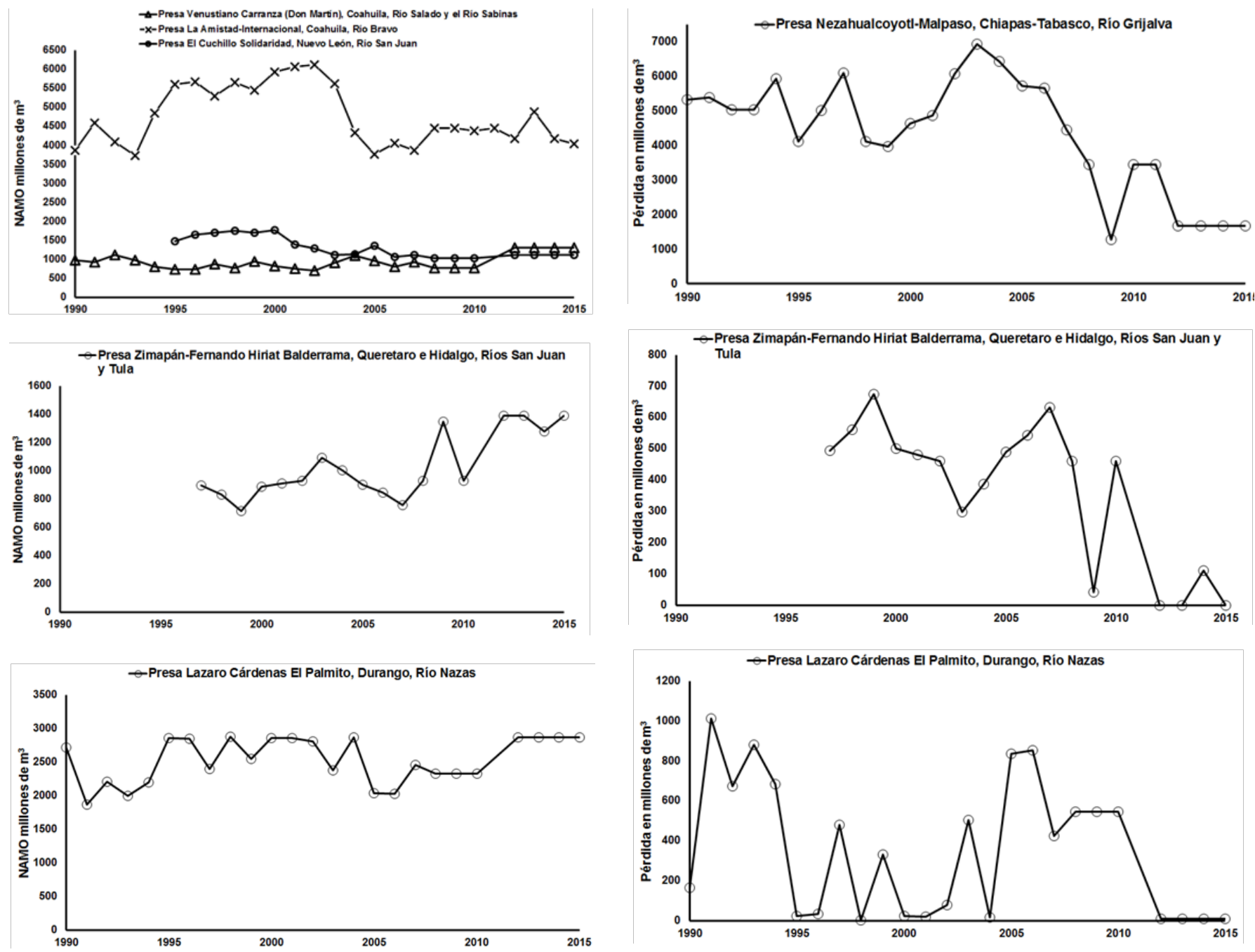

${ }^{1400}$ । -Presa Lazaro Cardenas (La Angostura), Sonora, Rio Bavispe

-Presa Salvador Alvarado - Sanalona, Sinaloa, Rio Tamazula EPresa Luis Donaldo Colosio (Huites), Sinaloa, Rio Fuerte
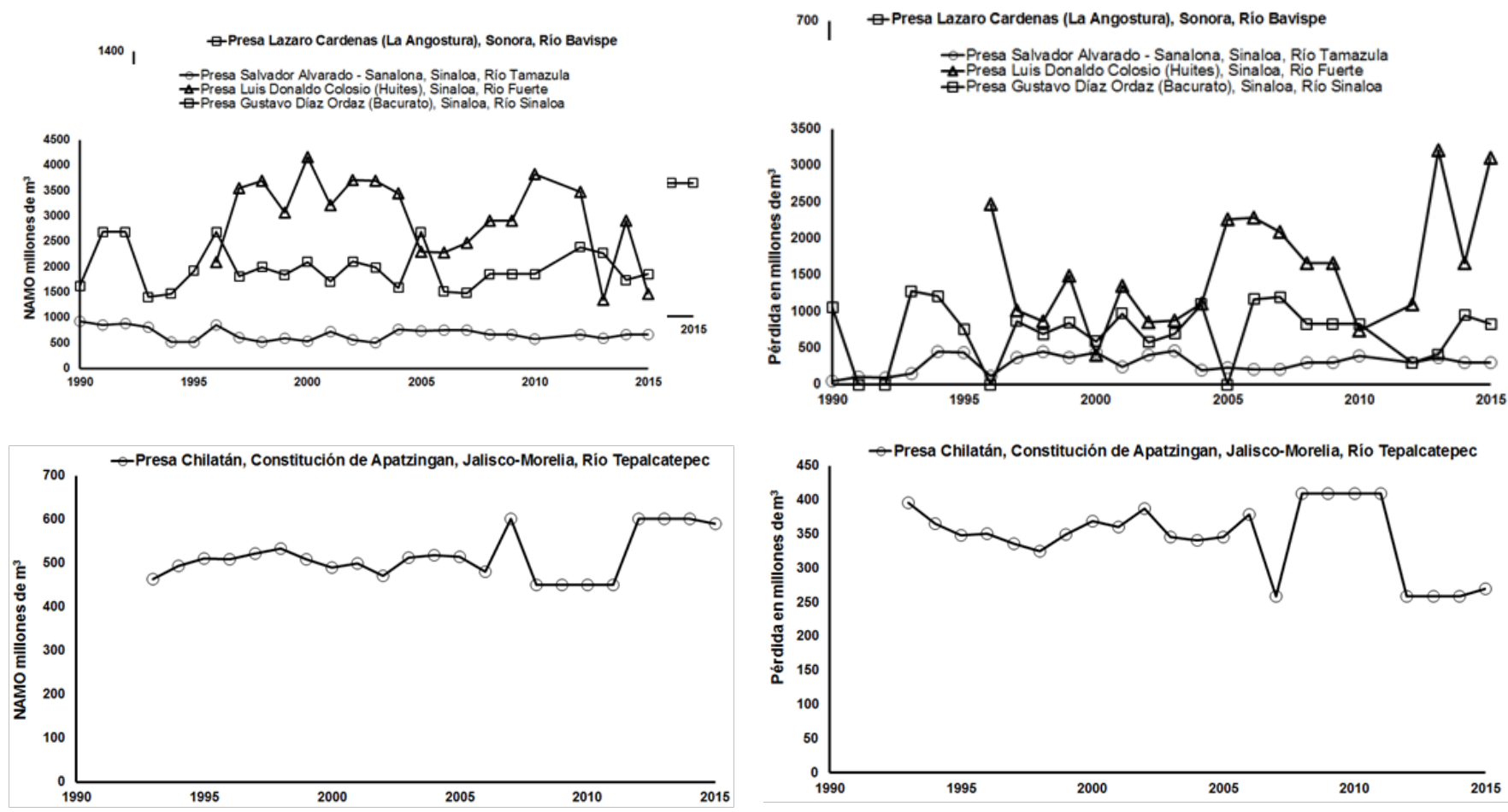

Citation: de la Lanza EG,Abarca F, Pulido SH. Environmental analysis of two inventories with more than 10 years of difference between natural and created wetlands. Int J Hydro. 20I8;2(3):353-362. DOI: 10.15406/ijh.2018.02.00096 

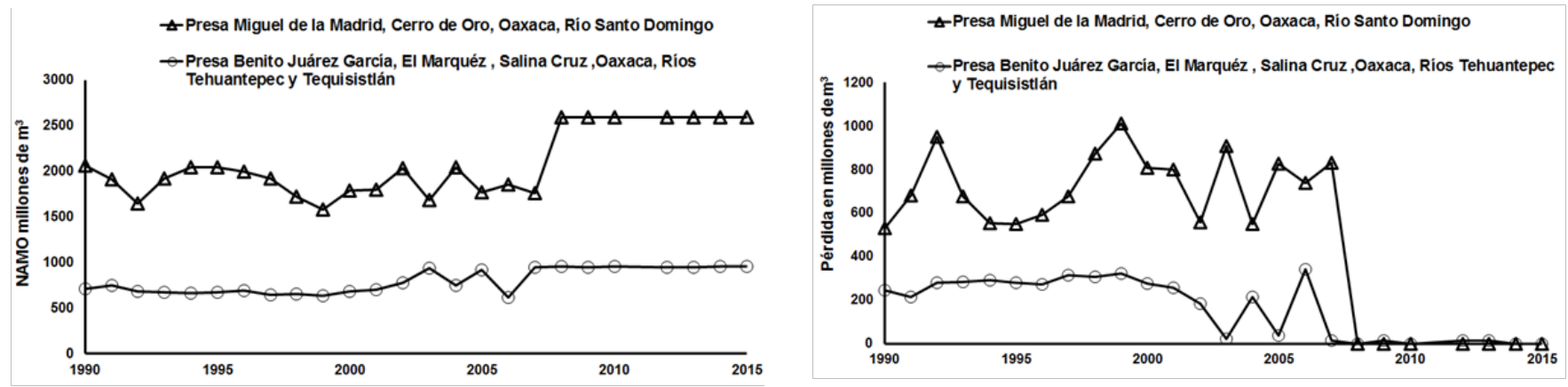

Figure 2 Change in the volume of some dams ordered from north to southern Mexico in a 15 -year period.

Table 2 Dams considered wetlands created organized by Administrative Regions, the number of years in which losses were recorded dammed volu

\begin{tabular}{|c|c|c|c|c|}
\hline & Dam & Study period years & Interval volume lost $\%$ & Administrative region \\
\hline I & The Oviachic I Alvaro Obregon, Sonora & $1990-2014$ & $3-48$ & II Northwest \\
\hline 2 & Adolfo Ruiz Cortines Mocuzari, Sonora & $1990-2015$ & 12 to 50 & II Northwest \\
\hline 3 & Lazaro Cardenas Angostura, Sonora & $1990-2015$ & $0-49$ & II Northwest \\
\hline 4 & Sanalona Salvador Alvarado, Sinaloa & $1990-2016$ & $5-55$ & III North Pacific \\
\hline 5 & Miguel Hidalgo y Costilla El Mahone, Sinaloa & $1990-2016$ & $2-46$ & III North Pacific \\
\hline 6 & Josefa Ortiz de Dominguez El Sabino, Sinaloa & $1990-2016$ & $3-49$ & III North Pacific \\
\hline 7 & Jose Lopez Portillo The Trough, Sinaloa & $1990-2016$ & $4-50$ & III North Pacific \\
\hline 8 & Gustavo Diaz Ordaz Bacurato, Sinaloa & $1990-2016$ & $1 \mathrm{I}-50$ & III North Pacific \\
\hline 9 & Ing.William Blake Aguilar El Sabinal, Sinaloa & $1990-2016$ & 10 to 48 & III North Pacific \\
\hline 10 & Ing.Aurelio Benassini Viscaíno Elota El Salto, Sinaloa & $1992-2010$ & II to 45 & III North Pacific \\
\hline $\mathrm{II}$ & Colosio Huites, Sinaloa & $1995-2016$ & $2-50$ & III North Pacific \\
\hline 12 & Infiernillo, Guerrero - Michoacan & $2008-2015$ & $0-45$ & IV Balsas \\
\hline 13 & Ing. Carlos Ramirez Ulloa El Caracol, Guerrero & $2000-2014$ & $17-49$ & IV Balsas \\
\hline 14 & Chilatán Constitution of Apatzingan, Jalisco & $1993-2015$ & $0-48$ & IV Balsas \\
\hline 15 & Jose Maria Morelos La Villita, Michoacán-Guerrero & $1990-2015$ & $14-37$ & IV Balsas \\
\hline 16 & President Benito Juarez El Marquez, Oaxaca & $1990-2014$ & $0-50$ & V South Pacific \\
\hline 17 & Toronto Lake La Boquilla, Chihuahua & $1990-2015$ & $5-41$ & VI Rio Bravo \\
\hline 18 & Francisco I. Log Virgin, Chihuahua & $1990-2015$ & $0-49$ & VI Rio Bravo \\
\hline 19 & Ing. Luis L. León El Granero, Chihuahua & $1990-2015$ & $0-49$ & VI Rio Bravo \\
\hline 20 & Don Martin Venustiano Carranza, Coahuila & $1990-2015$ & $0-48$ & VI Rio Bravo \\
\hline 21 & International La Amistad, Coahuila-Texas & $1990-2015$ & $7-47$ & VI Rio Bravo \\
\hline 22 & Jose Lopez Portillo Cerro Pietro, Nuevo León & $1990-2015$ & $0-44$ & VI Rio Bravo \\
\hline 23 & Knife - Knife Solidaridad, Nuevo León & $1995-2015$ & $0-48$ & VI Rio Bravo \\
\hline 24 & Ing. Marte R. Gomez sugar, Tamaulipas & $1990-2016$ & $0-45$ & VI Rio Bravo \\
\hline 25 & International Falcon, Tamaulipas & $1990-2015$ & $6-48$ & VI Rio Bravo \\
\hline 26 & Mexican Federalism San Gabriel, Durango & $1990-2015$ & $0-50$ & VI Rio Bravo \\
\hline 27 & Lazaro Cardenas "The Palmito" Durango & $1990-2016$ & $0-50$ & VII Central Basins of the North \\
\hline 28 & Francisco Zarco The Tórtolas, Durango & $1990-2015$ & 17 to 50 & VII Central Basins of the North \\
\hline 29 & Plutarco Elias Calles, Aguascalientes & $1990-201 \mid$ & $8-49$ & VIII Lerma-Santiago-Pacific \\
\hline 30 & Solís, Guanajuato & $1990-2014$ & $0-49$ & VIII Lerma - Santiago - Pacific \\
\hline 31 & Manuel M., Santa Rosa, Jalisco & $1990-2015$ & $0-46$ & VIII Lerma-Santiago-Pacific \\
\hline 32 & El Cajon, Tomatlan, Peña, El Tule, Jalisco & $1990-2014$ & $0-42$ & VIII Lerma-Santiago-Pacific \\
\hline 33 & General Ramon Crown Madrigal Trigomil, Jalisco & $1995-2015$ & $0-46$ & VIII Lerma-Santiago-Pacific \\
\hline 34 & Aguamilpa Solidaridad Nayarit & $1995-2015$ & 10 to 56 & VIII Lerma-Santiago-Pacific \\
\hline 35 & Tinder Nayarit & $2013-2015$ & II to 44 & VIII Lerma - Santiago - Pacific \\
\hline 36 & Chicayán Stone,Veracruz & $1990-2010$ & $0-41$ & IX Northern Gulf \\
\hline 37 & Temascal President Miguel Aleman, Oaxaca & $1990-2015$ & $22-49$ & X Gulf Center \\
\hline 38 & $\begin{array}{l}\text { Netzahualcóyotl, Malpaso or Cataracts, Chiapas- } \\
\text { Tabasco }\end{array}$ & $1990-2013$ & $2-50$ & XI Southern Border \\
\hline 39 & La Angostura or Dr. Belisario Dominguez, Chiapas & $1990-2015$ & $13-72$ & XI Southern Border \\
\hline 40 & Manuel Moreno Torres Chicoasén, Chiapas & $1990-2015$ & $\mathrm{I}-36$ & XI Southern Border \\
\hline
\end{tabular}




\section{Mangroves}

To estimate mangrove area, 1999 was compared with that published by $\mathrm{CONABIO}^{10}$ where some similarities in coverage (Table 3 ) were found, as well as inequalities that could be due to the time differences in monitoring and deforestation for urban and industrial, mainly expansion. Similarity in descending order was: Campeche, Yucatan, Baja California Sur, Colima, Oaxaca (Table 3). In this analysis, it was estimated global loss has 65.887ha (9.1\%) between 1999 and 2009. In the Nayarit Berlanga Robles ${ }^{29}$ determined between 1973 to 2011 more detrimental has mangrove $13.000 \mathrm{ha}$; this decline has apparently been ongoing for the change of land use (agriculture, aquaculture, roads and tourism); particularly the poor coastal management as openings of channels to increase marine communication, which led to a great loss of life, but recently the $\mathrm{CONABIO}^{14}$ has pointed to a gain of 10,781 ha represents $1.4 \%$, this increase does not mean that it has offset the losses, since changes in land use are continued. Yucatan and Oaxaca are the states that recorded a coastal tourism growth accelerated ${ }^{30}$ including agriculture they have also influenced this community. In Sinaloa and Tabasco, growth has been agricultural and land use change, which could justify the decrease of this type of wetland. ${ }^{31}$ As for other specific hydrophilic vegetation in 1999 by the CNA, highlighted by its increased coverage and in decreasing order: Tabasco, Campeche and Quintana Roo, with of 1,095,616ha. Comparing the total areas of mangroves between 1999 and 2009 a loss of 65,887 ha could be justified by the type and the methodology used in the evaluation, uncertainty of information and most importantly was calculated bythe lack of strict regulations in its conservation with an advance not registered in deforestation, among others. If determined is compared in 1999 by the CNA $(721,554 \mathrm{ha})$ with regard by CONABIO in 2015 (775,555ha) a difference of 43,220 ha, whose ratios were calculated and exposed. CONABIO it refers to an area of mangrove 764,774ha in the year 2010; however, in 2015 was 7,75,555ha it has determined an increase of 10,781 ha of mangrove and its associated coverage, a result of including the disturbed mangrove and other wetlands.

Table 3 Comparison of mangrove areas by state calculated for 1999 and 2005 to 2012

\begin{tabular}{|c|c|c|c|c|c|}
\hline \multicolumn{3}{|c|}{ Coverage of wetlands CNA 1999} & \multicolumn{3}{|c|}{$\begin{array}{l}\text { Coverage mangroves, coverage at I: } 50000, \\
\text { CONABIO (2009) }\end{array}$} \\
\hline STATE & Mangrove & $\begin{array}{l}\text { Hydrophilic } \\
\text { other } \\
\text { vegetation }\end{array}$ & Region & State & ha \\
\hline & ha & ha & & & \\
\hline Baja California & 0 & 3241 & North pacific & & \\
\hline $\begin{array}{l}\text { Baja California } \\
\text { Sur }\end{array}$ & 23285 & 0 & & Baja California & 28 \\
\hline Campeche & 196495 & 178.709 & & $\begin{array}{l}\text { Baja California } \\
\text { Sur }\end{array}$ & 24321 \\
\hline Colima & 3330 & 1,220 & & Sinaloa & 11225 \\
\hline Chiapas & 57382 & 48.184 & & Sonora & 9353 \\
\hline Guerrero & 6499 & 9922 & & Nayarit & 66911 \\
\hline Jalisco & 3773 & 2059 & Pacific Center & & \\
\hline Michoacán & 0 & 8878 & & Jalisco & 2023 \\
\hline Nayarit & 82847 & 379 & & Colima & 3192 \\
\hline Oaxaca & 17500 & 1015 & & Michoacán & 1500 \\
\hline Quintana Roo & 27336 & |57.39| & & South Pacific & \\
\hline Sinaloa & 96159 & 6493 & & Guerrero & 8,093 \\
\hline Sonora & 7542 & 317 & & Oaxaca & 15118 \\
\hline Tabasco & 51624 & 522827 & & Chiapas & 39101 \\
\hline Tamaulipas & 4139 & 26761 & Gulf of Mexico & & \\
\hline Veracruz & 57713 & 111200 & & Tamaulipas & 2410 \\
\hline Yucatán & 85930 & 17020 & & Veracruz & 34089 \\
\hline
\end{tabular}


Table Continued

\begin{tabular}{|c|c|c|c|c|c|}
\hline \multicolumn{3}{|c|}{ Coverage of wetlands CNA 1999} & \multicolumn{3}{|c|}{$\begin{array}{l}\text { Coverage mangroves, coverage at I: } 50000 \text {, } \\
\text { CONABIO (2009) }\end{array}$} \\
\hline STATE & $\begin{array}{l}\text { Mangrove } \\
\text { ha }\end{array}$ & $\begin{array}{l}\text { Hydrophilic } \\
\text { other } \\
\text { vegetation } \\
\text { ha }\end{array}$ & Region & State & ha \\
\hline \multirow[t]{6}{*}{ TOTAL } & 721554 & 1095616 & & Tabasco & 35191 \\
\hline & & & Yucatan & & \\
\hline & & & & Campeche & 196552 \\
\hline & & & & Yucatán & 80528 \\
\hline & & & & Quintana Roo & 64155 \\
\hline & & & & TOTAL & 655667 \\
\hline
\end{tabular}

*Surfaces like mangrove loss

\section{Conclusion}

Natural wetland important concept for its broad and diverse ecosystem services have recently added you anthropogenic created or artificial which has diversified not only their definition, inventory and most importantly, their impact or impact on the physical stability of natural wetlands and particularly in the environmental field. In the case of dams as created wetlands or artificial, both its construction where there is an environmental disturbance, such as the increase in number with wide variation in surface and volume are associated with interannual and intra-annual climate variability, which can lead a crisis in water availability in the social and economic; even potentiate their disruptive effect on the biotic and abiotic environment. According to the above, it is advisable to carry out inventories of the two types of wetlands, especially focused on the conservation of natural and water availability of those created as the population increase, needs and activities of all kinds. Taking into account an increase of 35\% population in 13 years, it is proposed that monitoring and inventories of natural wetlands are made between five to ten years, approximately; even within similar to the dams associated with climatic cycles (e.g. decadal) of rain that increase rainfall and river runoff fills dams, consequently, both for better handling time. However, dams, despite the influence of these climatic cycles, there are losses in their impounded area for agricultural activities considered consumptive, which have increased in number (approximately $58 \%$ ) in 10 years (1999-2012), but decreased the fill volume $(>25 \%$ approximate average). One reason not to consider dams as wetlands, is its annual or interannual variability (considered short cycle in the use of water), which may mean not only the great loss experienced, but the strong pressure exerted on surrounding natural wetlands, whose permanence or existence is compared centuries (average 50 years) created although there are few exceptions. Mangroves, as a specific case of wetland, showed declines in their coverage between 1999 and 2012 , as a result of various human activities that in the last inventory of 2017 with better methodology, has been continuously confirmed; despite this, the CONABIO noted that in some mangroves was an increase by colonization of new areas, which may be associated with hydrogeological dynamics.

\section{Acknowledgement}

None.

\section{Conflict of interest}

The author declares there is no conflict of interest.

\section{References}

1. De la Lanza Espino G, Carbajal Pérez JL, Hernán $\backslash d e z$ Pulido S. Brief analysis of Tropical Cyclones in 162 years, coinciding with climatic variations and cyclic atmospheric factors of the Mexican Pacific and the Gulf of Mexico. In: Vázquez Botello, et al. editors. Vulnerability of coastal areas of Latin America. Institute of Biology, UNAM-EPOMEX; 2017: 29-54.

2. Secretariat of the Ramsar Convention. Manual of the Ramsar Convention. Guide to the Convention on. 2013.

3. Ley de Aguas Nacionales. Last Reform DOF 18-04-2008. Chamber of Deputies of the H. Congress of the Union. General Secretariat for Parliamentary Services Center for Documentation, Information and Analysis. 2008.

4. Warner BG. Classification of wetlands. In: Abarca FJ, Herzig M, editors. Manual for the management and conservation of wetlands in Mexico. Pronatura: NAWCC. 2002.

5. Ramsar. Manual de la Convención, 6th editión. Recuperado el 4 de noviembre de 2010. 2013;1-120.

6. CBD. Viviendo en armonía con la naturaleza. Secretaría del Convenio sobre la Diversidad Biológica. 2011;1-68.

7. National Wetland Policies Colombia. República de Colombia Ministerio del Medio Ambiente Consejo Nacional Ambiental Política Nacional para Humedales. Interiores de Colombia Estrategias para su Conservación y Uso Racional Bogotá. 2011;1-138.

8. Cabrera Sánchez JA, García O, Soto E. Ecology and landscape of the wetlands of Matanzas, Cuba. Memories II International Symposium "Wetlands 94". Editorial Academy Havana. 1995.

9. Rector Strategy Paper. National Inventory of Wetlands. Ministry of the Environment and Natural Resources (SEMARNAT). 2008.

10. Comisión Nacional para la Biodiversidad (CONABIO). Manglares de México. Extensión y distribution. 2nd edition. Comission Nacional para el Uso y Conocimiento de la Biodiversidad. 2009;100.

11. FAO. Los manglares de América del Norte y de América Central (19802005). Informers Nacionales. Forest Resources Assessment Programme. Working Paper 137, Food and Agriculture Organization of the United Nations. Rome, Italy. 2007. p. 1-161. 
12. Olmsted I. Wetlands of Mexico. In: Whigham DF, Dykyjová D, Hejny $\mathrm{S}$, editors. Wetlands of the world: Inventory, ecology and management. Dordrecht, The Netherlands: Kluwer Academic Publishers. 1993:637677.

13. Dugan P. Wetlands in danger: A World Conservation Atlas. Oxford University Press, New York. 1993

14. Comission Nacional para la Biodiversidad CONABIO. Manglares de México, Actualization y exploration de los datos del sistema de monitored 1970/1980-2015. CONABIO. 2017. p. 1-130.

15. Jiménez S. Vida útil de las presas. Prezi. 2014.

16. Alcocer J, Hammer UT. Saline lake ecosystems of Mexico. Aquatic Ecosystem Health and Management. 1998;1(3-4):291-315.

17. Comission Nacional Del Agua (CNA). Basic Compendium of Water in Mexico. CNA, México. 1999.

18. Comission Nacional Del Agua (CONAGUA). Statistics on Water in Mexico, 10 years of presenting water in figures. CONAGUA. 2010

19. Cowardin LM, Carter V, Golet EC, et al. Classification of wetlands and deep-water habitats of the United States. US Fish and Wildlife Service FWS/OBS 79/31. 1979;1-142.

20. Comisión Nacional de áreas Protegidas (CONANP). Los humedales de México. CONANP. 2014

21. Aquabook. Consumptive and non-consumptive uses. DRE.2018.
22. Secretarial de Agriculture y Pesca (SAGARPA). Agricultural production statistics 1980-2015. SAGARPA. 2016.

23. De la Lanza-Espino G, Gómez Rodríguez G. Analysis of the short term geo-environmental evolution of an endorrey basin using satellite images: the case of Tecocomulco Lagoon, Mexico. Investigaciones Geográficas, Boletín del Instituto de Geografía. 2005;58:66-79.

24. Red Madrileña de Tratamientos Avanzados de Aguas Residuales (REMTAVARES). Humedales artificialness como sistemas naturales de depuración de aguas residuales. Conceptos e historia. 2013.

25. Comisión Nacional del Agua (CONAGUA). Estadísticas del agua en México. Gobierno de la República. CONAGUA. 2016.

26. Comisión Nacional del Agua (CONAGUA). Estadísticas del agua en México. Gobierno de la República, CONAGUA. Edición 2014.

27. García E. Modificaciones al sistema de clasificación climática de Köppen. Quinta Edición Instituto de Geografía. 2004;1-98.

28. Martínez V. Contienen 19\% de su capacidad presas de Zacatecas CONAGUA Press. 2012

29. Berlanga-Robles C. La deforestación de los manglares y la pesquería del camarón en Marismas Nacionales. Jornada Ecológica. 2012.

30. INEGI. Humedales potenciales. Humedales potenciales. 2014.

31. Instituto Nacional de Estadística y Geografía (INEGI). Humedales potenciales. 2012 . 